International Journal of Business and Management Review

Vol.8, No.1, pp.1-17, January 2020

Published by ECRTD-UK

Print ISSN: 2052-6393(Print),

Online ISSN: 2052-6407(Online)

\title{
CREATING A COMPELLING BRAND FOR GHANAIAN TECHNICAL UNIVERSITIES TO ATTRACT QUALIFIED LECTURERS: MANAGEMENT'S PERSPECTIVE
}

\author{
Justice Solomon Korantwi-Barimah \\ Faculty of Business and Management Studies, Sunyani Technical University, Sunyani-Ghana \\ Faisal Mohammed \\ Faculty of Business and Management Studies, Sunyani Technical University, Sunyani-Ghana \\ Peprah-Amankonah Godfred \\ Directorate of Finance, Sunyani Technical University, Sunyani-Ghana
}

\begin{abstract}
This study aimed at exploring management members' views on branding Ghanaian technical universities to attract qualified lecturers. The justification for the study stems from the fact that although a considerable amount of organizational branding studies have been conducted, not much has focused on Ghanaian technical universities. A qualitative approach is applied, adopting semi-structured interviews to collect data from seven $(N=7)$ management members of Sunyani Technical University. The study discovered five themes that attract high-quality lecturers to the institutional brand of technical universities. The practical implications of this study are that the findings will assist technical university management and by extension all other higher learning institutions in creating a compelling organizational brand that attracts and retains quality lecturers. This study contributes significantly to the creation of new knowledge in strategic areas that constitute an attractive brand of technical universities to attract and maintain quality lecturers.
\end{abstract}

KEY WORDS: Ghanaian technical universities, compelling brand, qualified lecturers, Organizational culture, strategic vision

\section{INTRODUCTION}

Branding has become a strategic issue of concentration for universities to communicate their strengths and corporate identity to meaningfully develop differentiated brands. Branding, as used in HR management, refers to the set of intangible attributes and qualities which attract the potential employees to offer their services to a particular organization (CIPD, 2015). Harsha and Shah (2011) have noted that decreasing worldwide limits and technological changes have intensified the significance of organizational branding of universities and higher learning institutions. The transfer of noble practices from the business sector to the field of academics, according to Wæraas and Solbakk (2009), marks the advent of branding of higher learning 
institutions. Harsha and Shah (2011) argue that an institutional brand's sovereignty is stated in the minds of people or viewers by the judgments, views, pictures, and experiences connected with the brand and what these customers have over the period learned, felt, observed and heard about the institutions. The introduction of global university rankings has affected the internationalization of universities, reflecting institutional brand and reputation, according to Stolz, Hendel and Horn (2010).

Balmer (2012) indicates that university leadership may need to disclose the institution's vision, mission, and approach to the remainder of its stakeholders. Biraghi and Gambetti (2015) view organizational branding as an ongoing strategic process that reflects management's attempts to capture organizational identity and communicate it reliably and appealingly to encourage stakeholder organizational identification and backing. Flake (2015) argues that no assets are as essential to organizational achievement as the picture they represent to the press, clients, shareholders and the public. Organizational branding epitomizes one of the most valued assets, according to Biraghi and Gambetti (2015), which businesses possess to effectively distinguish themselves within the competitive world. According to CIPD (2015), an employer brand conveys the company's value proposition, that is, the totality of the company's culture, systems, attitudes and employee relationships and it encourages the employees to share goals to achieve success, profitability and job satisfaction. Kasekende et al., (2018) observe that organization cultures and systems imbed a number of things including rewards, people orientedness and strategies for functional HRs development both technical and managerial. Gilliver (2009) argues that employer brand identifies an organization in the marketplace and makes it unique.

Consequently, the universities need to attract skilled lecturers capable of ensuring long-term sustainability and quality (Makondo, 2014). As lecturers play a crucial role in a university's success, it is important to nurture an attractive organizational brand that would attract them to the institutions. However, at Ghana's technical universities, attracting top quality and skilled lecturers remains a challenge since the institutions are constantly competing with traditional universities for talent. Most often, the traditional universities are mostly favoured by skilled lecturers due to public prestige associated with those universities. Besides, the technical universities' brand is affected by the low parity of esteem between it and that of the traditional universities. Though considerable amount of organisational branding research has been conducted (Solbakk, 2009; Harsha \& sha, 2011; CIPD, 2015), none of these studies has addressed the question of management's views on branding technical universities to attract qualified lecturers.

A study by Onah and Anikwe (2016) disclosed that African universities, including those in Ghana, function under severe resource constraints, posing serious obstacles to stakeholders. 
International Journal of Business and Management Review

Vol.8, No.1, pp.1-17, January 2020

Published by ECRTD-UK

Print ISSN: 2052-6393(Print),

Online ISSN: 2052-6407(Online)

Besides, unattractive remuneration procedures continue to impede the institutional brand of African universities as noted by Makondo (2014). In this context, the present study attempted to investigate management members' opinions on a technical university as a brand to attract quality lecturers. In particular, the study dealt with the following research questions:

- What are management members' views on the present state of STU's organizational brand?

- What are the elements of a convincing technical university brand to manage lecturers efficiently?

The motivation for this research was driven by the fact that, irrespective of the mainly known importance of organizational branding as a manner to gain competitive advantage, studies in organizational branding continuously suffer from highly fragmented positions, making it difficult to recognize its importance (Biraghi \& Gambetti, 2015). The present study explores the concept of organisational branding in relation to a technical university by dividing it into six brief components, which are organizational culture, reputation, strategic vision, intended image(s), constructed image and organisational identity.

\section{LITERATURE/THEORETICAL UNDERPINNING}

\section{Factors influencing the organizational branding of a university Organisational culture}

Pauzuoliene and Mauriciene (2012) define factors affecting the organizational branding of a university as a scheme of interaction between basic assumptions, beliefs, views, sacraments, past, customs and symbols transmitted in all positions of organizational management. Kuh and Whitt (2000) observed that university culture is a particular form of organizational culture defined as the collaborative and mutually affecting agreements of customs, values, practices, dogmatisms and assumptions regulating the conduct of individuals and organizations within universities and providing a reference structure within which to determine the significance of trials and activities. A research by Naidoo (2013) discovered that real and long-lasting academic quality in universities would most probably happen when enabling and transforming roles reinforce collegiate and revolutionary cultures. Ghana's newly converted technical universities are attempting to build a fresh and shared institutional culture. This requires the disintegration of institutional culture to bring about the rebuilding of a new culture.

\section{Reputation}

Organizational reputation is often regarded as how decent, respected, valued and/or valued an organization is (Dowling \& Moran, 2012). These features lead to organizations gaining confidence, which, as Covey and Merrill (2006) stated, subsequently helps individuals to have 
International Journal of Business and Management Review

Vol.8, No.1, pp.1-17, January 2020

Published by ECRTD-UK

Print ISSN: 2052-6393(Print),

Online ISSN: 2052-6407(Online)

faith in the organization's reliability, skills and future strategies. Along these lines, a healthy reputation becomes strategic by improving credibility of service providers and consumer confidence, thereby reducing risk and associated transaction fees (Dowling \& Moran, 2012). Accordingly, Raithel and Schwaiger (2015) felt that businesses should concentrate more on reputation-growing operations aimed at customers and staff that concentrate more on non-monetary aspects of reputation, including improving the quality of product and service, promoting an appealing industrial atmosphere and engaging in social responsibility operations.

Terblanche (2015) argues that not only do noble organizational reputations hold the probability of value creation, but they also make it impossible for rival organizations to emulate due to the intangible nature of the reputation of organizations. Studies indicate that lecturers' mobility decisions are typically driven by the host universities' reputation, available study resources and the compatibility between their work post and study preferences (Agarwal \& Ohyama, 2013; De Grip, Fouarge \& Sauermann, 2010). Williams and Omar (2014) contend that universities' administration and efficiency is largely linked to the search for respect or reputation. Alessandri, Yang and Kinsey (2006) emphasize three areas of university reputation: academic enactment quality, external enactment quality, and emotional commitment. Brewer and Zhao (2010) recognized management, teaching, research, service, and equity as the five essential elements covering universities' overall reputation.

\section{Strategic vision}

It has been observed by Balmer, Stuart and Greyser (2009) that organizations' strategic vision indicates the organizations' perfect strategic (future-oriented) position within a timeframe. Balmer et al. (2009) further state that the strategic vision is determined after the organizational skills, property, other competing organizations and differences in the political, economic, moral, social and technological environment are dissected and analyzed. As part of best practices, healthy educational organizations track their decision making through strategic plans (Walker, 2011). Mintzberg (as quoted in Walker, 2011) cautioned that the core of strategic plans should be:

"While certainly not extinct, strategic planning dropped from its platform some time ago, due to the reality that planning commonly interrupts strategic thinking, causing confusion among executives between real vision and figure manipulation. This confusion lies at the root of the problem, which is that visions, as opposed to plans, are the most effective strategies.

Özdem (2011) believes that a sound vision statement should highlight a unique characteristic of an organization that distinguishes it from others. The author further recommends that all parties with special concern in organizations should understand and internalize their vision. Mayfield, Mayfield and Sharbrough (2015) posit that a vision of such nature needs top 
management to provide suitable communication. A strategic vision and related moral messages show good-will and appreciation for the parties concerned and promote the development of the well-being of these stakeholders (Mayfield et al., 2015).

\section{Intended image(s)}

The expected image of an organization is, according to Balmer et al. (2009), the organization's desirable or aspiring future standing. Intended image resides in the hearts and minds of organizational managers; impliedly, what they foresee the identity of the organization to be. Hugo-Burrows (1993) contends that leadership decisions control how far the required organizational image is transformed into policies and programmes aimed at showing the organizational image embedded in the primary groups of stakeholders. Podnar (2014) argues that building a suitable programme to express the coveted institutional goodwill is incredibly difficult if the management fails to understand who the organization is and what are its vision and future intentions.

Dolphin and Reed (2011) recognize that organizations are searching for favorable approaches from their key patrons, just as organizations are searching for a broader view of their purpose and culture. The focus of these desirable opinions is to help secure a definite basis for the business connection between businesses and their societies (Dolphin \& Reed, 2011). A research by Wood and Somerville (2008) found that, for example, when employees reflected on a required university's image, debates were based on what they believed ought to be achieved over the next 10 years and how a particular corporate standing could lead to achievement, as against getting caught up in favorite colors and preferred types. Sunyani Technical University's vision is to become a top-notch technical university for the provision of higher education in engineering, science and technology-based disciplines, technical and vocation education and training with an entrepreneurial drive in Sub-Saharan Africa and promotes the choice to become familiar with the core values of hard work, professionalism and responsiveness (STU's Strategic Plan, 2015-2020).

\section{Construed image}

Balmer et al. (2009) posit that the organizations' constructed image refers to the descriptions and reputations of organizations that clienteles and different stakeholders have adopted. According to Helm, Liehr-Gobbers and Storck (2011), the organizations' constructed image denotes having the impression of what others think of them. Dolphin and Reed (2011) mentioned that constructed images are essential as the institutions reflect on reputations in the institutional mirror both as valued assets and self-replications. Constructed image is a vital part in identity creation based on procedures for identification and differentiation (Cian \& Cervai, 2014). Organization members' views on what outsiders think of their organization can have an influence on the perceptive identification of organizations and their feelings as well as their 
self-esteem assessments (Cian \& Cervai, 2014). It has been observed by Dolphin and Reed (2011) that constructed images could be a major tool through which institutions can anticipate the ever-changing expectations in their institutional atmosphere.

\section{Organisational identity}

Jansen and Roodt (2014) claim that organizational identity is often misconstrued for other related concepts such as organizational identification, membership of the organization, and organizational duty. According to Lane and Scott (2007), organizational identity represents those qualities or characteristics of an organization that includes its principles, objectives and operations. Martin, Burke and Cooper (2011) argue that certain characteristics of an organization's identity, such as its country of origin, its history, and the products and services offered, are long-lasting. Nonetheless, in the view of its staff and other parties concerned, whether a firm is regarded as honorable or not, for example, may differ. Huisman and Pausits (2010) observed that most universities recognize their position as having to do with their conventional two-fold; teaching and research activities but do not seem to fully understand their role as a long-term learning provider. The authors also noted that the increasing market rivalry for continuing education is compelling universities to review their programmes, carry out market evaluations and strategically reposition themselves.

\section{RESEARCH METHODOLOGY}

\section{Research design/Research approach}

According to Creswell (2014), the choice of a research approach is further determined by the essence of the research issue being investigated, the researcher's understanding and the individuals to whom the study affect. This study adopted a qualitative approach. This approach was adopted and considered to be more relevant due to the fact that there is a relatively small number of individuals in management positions within the university being studied. Furthermore, as organizational branding is promoted by employers and focused on employees, a qualitative approach was required by the nature of the study. In the context of this research, the university management promotes organizational branding and it is focused on lecturers. Consequently, the researchers found it prudent to obtain thorough views on organizational branding from the university's management members through a qualitative inquiry via interviews.

\section{Research strategy}

A case study strategy has been followed in this study as it was considered best suited to the researchers' objective of investigating a current phenomenon in a real-life condition (Bryman $\&$ Bell, 2015). From semi-structured interviews, the themes were extracted and confirmed by scrutinizing the existing literature. In this study, a case study approach falls under the paradigm 
of interpretation (Yin, 2012). The ontological belief in this case is that reality is locally and precisely built.

\section{Research setting}

A sample of 7 management members from Sunyani Technical University was included in the research setting in this study. All the participants were personally interviewed in their offices. Before the interviews were conducted, the researchers obtained the participants' approval.

\section{Research method}

\section{Entry and researcher roles}

The researchers personally approached the interview participants and requested interviews upon obtaining prior permission from the relevant university authorities through a request letter. Before answering any of the questions, the participants were required to consent. Anonymity was upheld and in compliance with the code of ethics, all information provided remains confidential.

\section{Sampling}

Seven management members participated in this study via interviews. Participants were selected on the basis of their work experience in higher education and their role in the university's organizational brand. Until data saturation was reached, the participants were interviewed one after the other in their offices. This study used purposive convenience sampling method; implying participants were selected based on their availability and preparedness to participate in the data collection process and the relevance of their contributions. The demographic distribution of participants is shown in Table 1.

Table 1: Demographic distribution of participants.

\begin{tabular}{llll}
\hline Participants & Gender & Qualification & Status/Rank \\
\hline 1 & Female & Master's degree & Domestic dean \\
2 & Male & Doctoral degree & Faculty dean \\
3 & Male & Master's degree & Deputy Reg. (HRD) \\
4 & Female & Doctoral degree & Executive management \\
5 & Male & Doctoral degree & Executive management \\
6 & Male & Master's degree & Senior management \\
7 & Male & Master's degree & Executive management
\end{tabular}

As can be seen from Table 1, the majority of the participants were men, making up $71.43 \%$ (five participants) of the sample. Majority (4) of the participants were in possession of a master's degree (57.14\%). In terms of managerial levels, the result shows $42.86 \%$ (three 
participants) to be in the executive level of management, another $57.14 \%$ (four participants) to be in the senior level of management. Only one out of the three participants in executive management is woman, that is, $33.33 \%$ of the entire sample as opposed to a hitting $66.67 \%$ of men in the entire sample in positions of management.

\section{Data collection method}

Using semi-structured interviews, qualitative data collection was carried out. The interviews aimed at revealing deeper insights by allowing new information and ideas to emerge from the results that would not have been revealed by the quantitative data. The interview sessions succeeded in specifically unraveling the views of members of management on organizational branding within the university under study. In line with this framework, the participants were asked to describe their experiences regarding organizational branding. The questions sought to determine the university's current organizational brand.

\section{Data recording}

The researchers considered it appropriate to capture audio recordings of the responses of the participants in order for these responses to be transcribed later due to the large volume of data normally obtained from a qualitative research. The researchers played back the audio recordings and the data were transcribed verbatim in a MS Word document to analyze the data collected.

\section{Data analysis}

A transcription process was used per Bernard and Ryan (2010), whereby the participants' recorded audio responses were converted into text (word document). In this study, the data analysis was used to expose the relations that existed throughout the phenomena and how these relations relate to the study's aggregate cultural setting (Leech \& Onwuegbuzie, 2008). Through open coding, each theme and sub-theme were labeled by the researchers to provide a description of newly discovered phenomena and the criteria for inclusion and exclusion. Thereafter, the codes generated were refined by axial coding and the labels and their descriptions were supported by verbatim quotations from the interview responses. They were further compared with literature and related studies to determine the validity of the data and also ensure that the main research question was properly addressed.

\section{Ensuring the research's quality and rigor}

The following approaches have been used to guarantee the study's quality and rigor in line with Sargeant (2012):

- Be careful of individual biases that may have impacted the results. 
International Journal of Business and Management Review

Vol.8, No.1, pp.1-17, January 2020

Published by ECRTD-UK

Print ISSN: 2052-6393(Print),

Online ISSN: 2052-6407(Online)

- Recognition and avoidance of prejudices in the sampling and ongoing evaluation of methods to ensure appropriate depth and importance of and evaluation of information collection.

- Keeping a thorough record, showing all the methods used to analyze the data and ensuring reliable and apparent explanations of the data.

- To support the findings, add a significant volume of verbatim explanations to the participant.

- Validating results by asking respondents to comment on the interview transcripts to determine whether the ultimate themes built substantially to reflect the ideas under consideration.

\section{RESULTS/FINDINGS}

\section{Reporting}

The results of this study were tabulated, showing the themes and different sub-themes emerging from the research. The themes and sub-themes are supported by verbatim quotations obtained from the responses given by the respondents during the interview. This has been performed per modern qualitative research strategy, involving validating or promoting understanding of the assumptions taken in specific study environments (Bowen, 2009).

\section{Findings}

Table 2 demonstrates how frequently the themes arose from the management members' interviews. The results in Table 2 indicate that the sub-themes that occurred frequently under the theme of organizational branding were work and environment, reputation and image, and organizational culture and identity.

\section{Table 2: Frequency of themes}

\begin{tabular}{ll}
\hline Theme and sub-themes & Frequency \\
\hline Organisational branding & 56 \\
Reputation and image & 13 \\
Organisational culture and identity & 11 \\
Strategic vision & 5 \\
Corporate social responsibility & 9 \\
Work and surrounding environment & 18 \\
\hline
\end{tabular}

\section{Theme: Organizational branding}

In this study, the most frequently occurred sub-theme under organizational branding was work and surrounding environment (mentioned 18 times). Other sub-themes emerging in lower 
International Journal of Business and Management Review

Vol.8, No.1, pp.1-17, January 2020

Published by ECRTD-UK

Print ISSN: 2052-6393(Print),

Online ISSN: 2052-6407(Online)

frequency order were reputation and image, organizational culture and identity, corporate social responsibility, and strategic vision.

\section{Sub-theme: Work and surrounding environment}

The most frequently occurred sub-theme in this study was work and the surrounding environment. The respondents felt that a working environment that allows lecturers to perform is essential to guarantee that they remain ahead as a technical university, as explained by this participant:

The most significant thing, of course, is the environment that I would say is our competitive edge to guarantee that we provide a favorable atmosphere for lecturers to establish themselves. (Participant 4, female, doctoral degree, executive management).

Furthermore, another participant said:

First, we provide a local atmosphere that is conducive to the focused job, research and teaching and learning. Secondly, it is essential to have an enabling atmosphere. They can get it if a lecturer requires time and flexibility. So allowing... in the sense that if I need cash to go and do research, with the option of traveling to do interviews, etc., then it must be accessible, allowing a lecturer to network as well. (Participant 5, male, doctoral degree, executive management).

Participants think that it is important for lecturers to express what is essential to them to enable management to provide the required work environment so that they grow and develop as lecturers as stated by these participants:

You need to plan on what you want to do and to accomplish that goal, the employer provides the enabling atmosphere to accomplish that goal and you need to do so. (Participant 1, female, master's degree, domestic dean)

And:

We provide an environment that is very conducive to studying. If you're a lecturer and you're not studying, you have to justify to me at this university. (Participant 3, male, master's degree, Deputy Reg.(HRD).

The respondents also explained that in terms of the university's geographical location, an appealing internal climate is also essential in affecting the choice of lecturers to remain at the university as stated by this respondent:

Another thing is that the environment also plays a very important part. If you ask the lecturers, they're going to tell you about a nice university closeness and all those sorts of stuff. They will tell you about the airport's proximity, there is an airport here in Sunyani, but it hasn't been functioning for a while. (Participant 6, male, master's degree, senior management). 
International Journal of Business and Management Review

Vol.8, No.1, pp.1-17, January 2020

Published by ECRTD-UK

Print ISSN: 2052-6393(Print),

Online ISSN: 2052-6407(Online)

Another participant also felt that it was advantageous to be working in such a setting as where their campus is located and that it has an aspect of attractiveness:

You can see that it is usually located in the center of the country, you know, when you compare it with a very busy city like Accra or Kumasi, you will see there is a difference... if you look at the price or the nature of living standards. (Participant 2, male, doctoral degree, faculty dean).

\section{Sub-theme: Reputation and image}

The participants emphasised that the university's high reputation and its objective of being recognized globally, for example, in top-quality research, teaching and learning, is what attracts their pool of talented lecturers as point out by the participants.

\section{Sub-theme: Organizational culture and identity}

The participants admitted that the university has an organizational culture and identity that is accommodating and appealing. The respondents expressed that within the university, there is a culture of empowering lecturers to achieve their greatest potential as stated by the following respondents:

I believe if you interview individuals who want to come here to work, they'll inform you that it's because there's a culture of empowering individuals in the university. (Participant 7, male, master's degree, executive management).

Other respondents cited the strongly rooted research culture as what makes the university appealing to lecturers:

For all this period, I have remained here because I want to see how I can contribute to the university's research culture. (Participant 5, male, doctoral degree, executive management).

Participants also stated that within the university there is an organizational identity, specifically within the faculties for which participants worked.

\section{Sub-theme: Corporate Social Responsibility}

The results indicated that lecturers are satisfied that they can immensely contribute through community involvement with their university, as per the answer given by the participants:

If you work at the college, the hypothesis is that you want to use your skill in this setting and that you want to contribute through your talent. (Participant 7, male, master's degree, executive management).

Another participant added:

I believe that most individuals would prefer to come to this university merely because of their contribution. Remember that this is a new technical university so if you see yourself making a 
International Journal of Business and Management Review

Vol.8, No.1, pp.1-17, January 2020

Published by ECRTD-UK

Print ISSN: 2052-6393(Print),

Online ISSN: 2052-6407(Online)

lot of contributions, particularly to the groups that profit from the university, I'd see it that way and then it provides you the chance to participate better as a community lecturer in terms of projects and so on. (Participant 1, female, master's degree, domestic dean).

A participant further mentioned that interest in community participation is a key factor in defining powerful job applicants:

You will see that the system engaged in recruitment and appointment, you will see that it is accomplished in such a manner that we also target the finest individuals so that when they come here, they also perform in terms of our needs, in terms of community participation. (Participant 4, female, doctoral degree, executive management).

The respondents also noted the significance of being able to make an important contribution to knowledge (teaching and learning) and to the bigger communities they serve as well.

\section{Sub-theme: Strategic Vision}

In this study, strategic vision occurred less commonly; nevertheless, respondents stated that it influences organizational branding achievement and how well stakeholders, particularly lecturers, will receive it. It was observed by some of the respondents that talent management is a lately integrated element of the university's policy, as demonstrated by these respondents:

In this university, we realize how important it is to manage our lecturers, thus is, why our new strategic plan even includes talent management as a key component. (Participant 7, male, master's degree, executive management).

And:

If you look at our new strategy, I don't know if you've looked at the strategy, it's the first time I've seen talent management in our strategy, do you know? So that's a new strategy now, I mean we're busy with implementation and I was very pleased about it. Now that's never been in our strategy before, so I think this is important for the first time, like our Vice-Chancellor and the likes. (Participant 3, male, master's degree, deputy registrar, HRD).

\section{DISCUSSION}

This study's main objective was to explore management members' views of a technical university as a brand for the attraction of qualified lecturers. Five sub-themes were identified as important for attracting high-quality lecturers to the institutional brand of technical universities. The sub-themes are work and environment, reputation and image, organizational culture and identity, corporate social responsibility, and strategic vision. 
International Journal of Business and Management Review

Vol.8, No.1, pp.1-17, January 2020

Published by ECRTD-UK

Print ISSN: 2052-6393(Print),

Online ISSN: 2052-6407(Online)

Work and the surrounding environment was the most frequently mentioned sub-theme in this research. The participants pointed out the significance of a conducive and attractive work environment when it comes to organizational branding for lecturers at the technical university. The findings are consistent with that of Biraghi and Gambetti (2015), who argue that universities need to offer a conducive and competitive work environment in order to gain loyalty of faculty. Several studies have shown that, among others, the mobility of lecturers is determined mostly by the research resources available to them (De Grip et al., 2010; Agarwal \& Ohyama, 2013).

The second most commonly mentioned sub-theme amongst the participants was reputation and image. Williams and Omar (2014) believed reputation is key to the effective management of higher learning institutions. Particularly, the participants agreed that a university's reputation and image is essential in guaranteeing an institutional brand that attracts more lecturers (see Raithel \& Schwaiger, 2015). Reputation helps increase the confidence of lecturers in the dependability and future plans of the institutions (Covey \& Merrill, 2006). Dolphin and Reed (2011) argued that in the institutional mirror, reputations are the valued assets and replica of the university itself.

The university's culture and identity arose as significant branding variables. The respondents endorsed the idea that the university has a related, accommodating and appealing culture and organizational identity. As Bitzer (2009) argues, although lecturers may not take care of their university's culture concerning their daily activities, each university has a predominant culture that is inevitable and controls the way things are done at each university. Sustainable academic performance would likely happen within universities when the enabling and transformation roles strengthen collegial and innovative cultures as Naidoo (2013) observed.

Corporate social responsibility was the fourth most common sub-theme mentioned by this study's respondents. According to Dolphin and Reed (2011), an initiative of corporate social responsibility is a major factor for attracting staff, and adds to the favorable attitudes of all the stakeholders in the community. Respondents agreed that technical universities could make a more significant contribution, through skilled lecturers, to the upliftment of societies. Implicitly, the universities can contribute to the well-being of bigger populations whilst providing quality products as Lamboy (2011) maintains.

The least discussed sub-theme among the respondents was Strategic vision, having it being raised by few respondents. Particularly, the respondents emphasized the significance of incorporating lecturer talent management into the university's human resources strategy. The emphasis on talent management is a clear demonstration that management has a strong 
strategic vision for the university. Therefore, a sound talent management vision can be said to help technical universities differentiate themselves from their rivals as Özdem (2011) noted.

\section{PRACTICAL IMPLICATIONS}

This study identified the main aspects of branding for attracting and maintaining talented lecturers in the technical universities. Consequently, managers of our universities need to build an attractive organizational brand and work environment where lecturers can grow and develop their potentials. Management also need to have the strategic foresight to develop a favourable working atmosphere that will add to the competitiveness and sustainability of technical universities, through their skilled lecturers. Through applied research and high-quality teaching and learning, this will equally enhance the university's reputation as the best employer to work with.

\section{CONCLUSION}

The study discovered reputation and image, organizational culture and identity, strategic vision, corporate social responsibility, and work and environment as the five themes that attract high-quality lecturers to the institutional brand of technical universities. Branding is a new and argumentative higher education study area that raises skepticism about its feasible application. Due to the continuing competition with traditional universities, Ghana's technical universities need to emphasize their distinctiveness, which involves creating a global institutional brand, which give rise to a fresh perspective on technical universities. This is a demonstration that branding has become a modern topic in educational management and generates a distinctive export product for the country. Similar to organizations, the universities also have a brand that helps them succeed. It can therefore be concluded that a more appealing brand would attract talent and more funds to the universities.

\section{FUTURE RESEARCH}

Some constraints were present in this study. The first limitation concerns the restricted body of studies that exist in the Ghanaian university education domain on organizational branding studies. Second, this study was conducted at one technical university and the study cannot, therefore, be generalized to other universities. Finally, the study sample was restricted to the perceptions of management members. Consequently, to provide a holistic perspective on technical university branding, it is suggested that other university groups such as lecturers and administrative employees be included in future studies. To develop a popular and compelling university organizational brand that will attract and maintain skilled lecturers to the universities, this study can also be extended to other traditional universities in Ghana and beyond. 
International Journal of Business and Management Review

Vol.8, No.1, pp.1-17, January 2020

Published by ECRTD-UK

Print ISSN: 2052-6393(Print),

Online ISSN: 2052-6407(Online)

\section{References}

Agarwal, R., \& Ohyama, A. (2013). Industry or academia, basic or applied? Career choices and earnings trajectories of scientists. Management Science, 59(4), 950-970. https://doi.org/10.1287/mnsc.1120.1582

Alessandri, S.W., Yang, S.-U., \& Kinsey, D.F. (2006). An integrative approach to university visual identity and reputation. Corporate Reputation Review, 9(4), 258-270. https://doi.org/10.1057/palgrave. crr.1550033

Balmer, J.M.T. (2012). Corporate brand management imperatives: Custodianship, credibility, and calibration. California Management Review, 54, 6-33. https://doi. org/10.1525/cmr.2012.54.3.6

Balmer, J.M.T., Stuart, H., \& Greyser, S.A. (2009). Aligning identity and strategy: Corporate branding at British Airways in the late 20th century. California Management Review, 51(3), 6-23. https://doi.org/10.2307/41166491

Bernard, H.R., \& Ryan, G.W. (2010). Analyzing qualitative data: Systematic approaches. Thousand Oaks, CA: Sage.

Biraghi, S., \& Gambetti, R.C. (2015). Corporate branding: Where are we? A systematic communication-based inquiry. Journal of Marketing Communications, 21(4), 260-283. https://doi.org/10.1080/13527266.2013.768535

Bitzer, E. (Ed.). (2009). Higher Education in South Africa: A scholarly look behind the scenes. Stellenbosch: African Sun Media.

Bowen, G.A. (2009). Document analysis as a qualitative research method. Qualitative Research Journal, 9(2), 27-40. https://doi.org/10.3316/QRJ0902027

Brewer, A., \& Zhao, J. (2010). The impact of a pathway college on reputation and brand awareness for its affiliated university in Sydney. International Journal of Educational Management, 24(1), 34-47. https://doi.org/10.1108/09513541011013033

Bryman, A., \& Bell, E. (2015). Business research methods. (4th edn.). Oxford, UK: Oxford University Press.

Cian, L., \& Cervai, S. (2014). Under the reputation umbrella: An integrative and multidisciplinary review for corporate image, projected image, construed image, organizational identity, and organizational culture. Corporate Communications: An International Journal, 19(2), 182-199. https://doi.org/10.1108/CCIJ-10-2011-0055 Covey, S.M.R., \& Merrill, R.R. (2006). The speed of trust. New York: Free Press.

CIPD, (2015). Employer Branding: A No-nonsense Approach, Chartered Institute of Personnel and Development, London.

Creswell, J.W. (2014). Research design: Qualitative, quantitative, and mixed methods approaches. (4th edn.). Thousand Oaks, CA: Sage.

De Grip, A., Fouarge, D., \& Sauermann, J. (2010). What affects international migration of European science and engineering graduates? Economics of Innovation and New Technology, 19(5), 407-421. https://doi.org/10.1080/ 10438590903434828 
International Journal of Business and Management Review

Vol.8, No.1, pp.1-17, January 2020

Published by ECRTD-UK

Print ISSN: 2052-6393(Print),

Online ISSN: 2052-6407(Online)

Dolphin, R., \& Reed, D. (2011). The fundamentals of corporate communications. Abingdon, OX: Routledge.

Dowling, G., \& Moran, P. (2012). Corporate reputations: Built in or bolted on? California Management Review, 54(2), 25-42. https://doi.org/10.1525/cmr.2012. 54.2.25

Gilliver, S. (2009), "Badenoch and Clark guide”, Employer Branding Essentials, 4(3):25-39.

Helm, S., Liehr-Gobbers, K., \& Storck, C. (2011). Reputation management: Management for professionals [Adobe Digital Editions version]. https://doi. org/10.1007/978-3-642-19266-1

Hugo-Burrows, M.M. (1993). Trends and strategies in the marketing of corporate image and identity in a politically-conscious South Africa. In R.L. King (Ed.), Minority marketing: Research perspectives for the 1990s: Proceedings of the 1993 Minority Marketing Congress (pp. 109-113). Switzerland: Springer International Publishing.

Huisman, J., \& Pausits, A. (Eds.). (2010). Higher Education management and development. Compendium for managers. New York: Waxmann Verlag.

Jansen, P.G.W., \& Roodt, G. (Eds.). (2014). Conceptualising and measuring work identity: South-African perspectives and findings. Dordrecht: Springer.

Kasekende, M., Mafabi, S. and Matongolo, A. (2018), "Retooling employer branding: the case of selected public universities in Uganda", The Journal of Organizational Excellence (in print).

Kuh, G.D., \& Whitt, E.J. (2000). Culture in American colleges and universities. In M.C. Brown (Ed.), Organization \& governance in higher education (5th edn., pp. 160- 169). Boston: Pearson Custom Publishing.

Lamboy, J.V. (2011). Implications of branding initiatives in higher education among trademarked institutions in California. Doctoral dissertation. Retrieved March 05, 2018, from http://repository.usfca.edu/cgi/viewcontent.cgi?article $=1007 \&$ context $=$ diss

Lane, V.R., \& Scott, S.G. (2007). The neural network model of organisational identification. Organisational Behaviour and Human Decision Processes, (104): 175-192. https://doi.org/10.1016/j.obhdp.2007.04.004

Leech, N.L., \& Onwuegbuzie, A.J. (2008). Qualitative data analysis: A compendium of techniques for school psychology research and beyond. School Psychology Quarterly, 23, 587-604. https://doi.org/10.1037/1045-3830.23.4.587

Makondo, L. (2014). Academic attraction and retention trends at a South Africa University. Journal of Social Anthropology, 5(2), 169-177.

Martin, G., Burke, R.J., \& Cooper, C.L. (Eds.). (2011). Corporate reputation: Managing opportunities and threats. Farnham, England: Gower Publishing.

Mayfield, J., Mayfield, M., \& Sharbrough, W.C., III. (2015). Strategic vision and values in top leaders' communications: Motivating language at a higher level. International Journal of Business Communication, 52(1), 97-121. https://doi. org/10.1177/2329488414560282

Naidoo, D. (2013). Reconciling organisational culture and external quality assurance in higher education. Higher Education Management and Policy, 24(2), 85-98. https://doi.org/10.1787/hemp-24-5k3w5pdwhm6j 
International Journal of Business and Management Review

Vol.8, No.1, pp.1-17, January 2020

Published by ECRTD-UK

Print ISSN: 2052-6393(Print),

Online ISSN: 2052-6407(Online)

Onah, F.O., \& Anikwe, O.S. (2016). The task of attraction and retention of academic staff in Nigerian Universities. Journal of Management and Strategy, 7(2), 9-20. https://doi.org/10.5430/jms.v7n2p9

Opoku, R., Abratt, R., \& Pitt, L. (2006). Communicating brand personality: Are the websites doing the talking for the top South African business schools? Journal of Brand Management, 14(1), 20-39. https://doi.org/10.1057/palgrave.bm.2550052

Özdem, G. (2011). An analysis of the mission and vision statements on the strategic plans of higher education institutions. Educational Sciences: Theory \& Practise, 11(4), 1887-1894.

Pauzuoliene, J., \& Mauriciene, I. (2012). Organisational culture development in Klaipeda Municipality. Socialiniai Tyrimai, 3(28), 121-132.

Podnar, K. (2014). Corporate communication: A marketing viewpoint. Abingdon, OX: Routledge.

Raithel, S., \& Schwaiger, M. (2015). The effects of corporate reputation perceptions of the general public on shareholder value. Strategic Management Journal, 36, 945-956. https://doi.org/10.1002/smj.2248

Sargeant, J. (2012). Qualitative research part II: Participants, analysis, and quality assurance. Journal of Graduate Medical Education, 4(1), 1-3. https://doi. org/10.4300/JGME-D-11-00307.1

Sunyani Technical University (2019). Strategic Plan (2015-2020). Ghana.

Stolz, I., Hendel, D.D., \& Horn, A.S. (2010). Ranking of rankings: Benchmarking twentyfive higher education ranking systems in Europe. Higher Education, 60(5), 507-528. https://doi.org/10.1007/s10734-010-9312-z

Terblanche, N.S. (2015). Customer-based corporate reputation: A study of supermarket customers. In K. Kubacki (Ed.), Ideas in marketing: Finding the new and polishing the old: Proceedings of the 2013 Academy of Marketing Science (AMS) Annual Conference (pp. 207-212). New York: Springer.

Walker, M. (2011). Grounding our vision: Brain research and strategic vision. Independent School, 70(4), 50.

Wæraas, A., \& Solbakk, M.N. (2009). Defining the essence of a university: Lessons from higher education branding. Journal of Higher Education, 57, 449-462.

Williams, R.L. Jr., \& Omar, M. (2014). Applying brand management to higher education through the use of the Brand Flux Model - The case of Arcadia University. Journal of Marketing for Higher Education, 24(2), 222-242. https://doi.org/10.1080/0884 